\title{
REDISCOVERY OF TETRANYCHUS ABACAE BAKER \& PRITCHARD, ADDITIONAL DESCRIPTION AND NOTES ON SOUTH AMERICAN SPIDER MITES (ACARI, PROSTIGMATA, TETRANYCHIDAE)
}

\section{Carlos H.W. Flechtmann ${ }^{1}$}

\begin{abstract}
The rediscovery of Tetranychus abacae Baker \& Pritchard, 1962 is reported and additional description and drawings presented. New host and distribution records for 19 species of spider mites (Tetranychidae) in South America are given. KEY WORDS. Spider mites, Tetranychidae, Agriculture, Distribution, Host plants.
\end{abstract}

Among the spider mites, acarina of the family Tetranychidae, are many important pests of Agriculture. Although practically all the major food crops and many ornamental plants are subject to their attack, information concerning the spider mites of South America is still scarce.

In this paper new distribution and host plant records for 19 species are reported from Brazil, Bolivia, Colombia, Venezuela, Peru, Argentina and Chile, and the rediscovery of Tetranychus abacae Baker \& Pritchard is presented, as well as additional description and drawings.

\section{Eutetranychus banksi (McGregor, 1914)}

Tetranychus banksi McGregor, 1914. Ann. Entomol. Soc. Amer. 7 (4): 358.

Tetranychus rusti McGregor, 1917. Proc. U.S. Natl. Mus. 51 (2677): 582.

Anychus vergani Blanchard, 1940. Rev. Fac. Agron. La Plata 3 (2): 24.

Eutetranychus banksi, McGregor, 1950. Amer. Midl. Natur. 44 (2): 268.

Known as the Texas citrus mite, this species occurs on a variety of hosts in Southern North America, Central and South America.

New record: on Hibiscus rosa-sinensis L. (Malvaceae), La Molina, Peru (U.G. Bacca leg., 1983).

\section{Mononychellus planki (McGregor, 1950)}

Tetranychus planki McGregor, 1950. Amer. Midl. Natur. 44 (2): 300.

Eotetranychus planki, Pritchard \& Baker, 1955. Pacific Coast Entomol. Soc. Mem. Ser. 2: 148.

Mononychellus planki, Wainstein, 1971. Zool. Zhurn. 50 (4): 589.

This species has been reported from Brazil, Puerto Rico, Colombia and Trinidad, mainly on soybean, peanut, and bean. It is distinctive in having a reticulate pattern on the dorsum of the body, especially surrounding the setal bases.

1) Departamento de Zoologia, Universidade de São Paulo (ESALQ). Caixa Postal 9, 13418-900 Piracicaba, São Paulo, Brasil. Researcher of the CNPq. 
New records: on Vigna edenantha (Fabaceae), Corrientes, Argentina (S. Caceres leg., VI-1991); on Sida glaziovii K. Sch. (Malvaceae), São Paulo (M.A. Garcia leg., IX-1988), and on Glycine max (L.) Merr. (Fabaceae), Paraná, Brazil (P. Cervi leg., I-1990).

Eotetranychus lewisi (McGregor, 1943)

Fig. 1

Tetranychus lewisi McGregor, 1943. Proc. Entomol. Soc. Wash. 45: 127.

Eotetranychus lewisi, Pritchard \& Baker, 1955. Pacific Coast Entomol. Soc. Mem. Ser. 2: 205.

This species was previously known from North and Central America on citrus, papaya, castor bean, olive, clover, Ceanothus sp. and Euphorbia marginata Pursh.

New record: on peach, Prunus communis L. (Rosaceae), San Benito, Cochabamba, Bolivia (J. Silva leg., X-1982).

\section{Schizotetranychus paezi Alvarado \& Freitez, 1976}

Fig. 2

Schizotetranychus paezi Alvarado \& Freitez, 1976. Agron. Trop., Maracay, 26 (2): 159.

This spider mite is known only from its description, on rice, in Venezuela.

New record: on rice, Oryza sativa L. (Poaceae), Palmira, Colombia (O.I.Mejia leg., V-1992).

\section{Oligonychus grypus Baker \& Pritchard, 1960}

Fig. 3

Oligonychus grypus Baker \& Pritchard, 1960. Hilgardia 29 (11): 526.

This species was described on sugar cane and grasses from Zaire (ExBelgian Congo).

New record: on sugar cane, Saccharum officinarum L. (Poaceae), Teotonio Vilela, Alagoas, Brazil (A. Mendonça F. leg., XI-1987), infesting a four month old field of sugar cane and the initial symptoms were intense yellow punctuations on the leaves, which later turned red and dried completely.

\section{Oligonychus punicae (Hirst, 1926)}

Fig. 4

Paratetranychus punicae Hirst, 1926. Proc. Zool. Soc. London 1926: 830.

Oligonychus punicae Pritchard \& Baker, 1955. Pacific Coast Entomol. Soc. Mem. Ser. 2: 335.

The avocado brown mite is a pest of avocados in California, USA; it is also known from grapes and pomegranate in Asia, Central and South America.

New record: on avocado, Persea americana Mill. (Lauraceae), La Cruz, Chile (R. Vargas M. leg., III-1988).

Revta bras. Zool. 13 (3): 569 - 578, 1996 

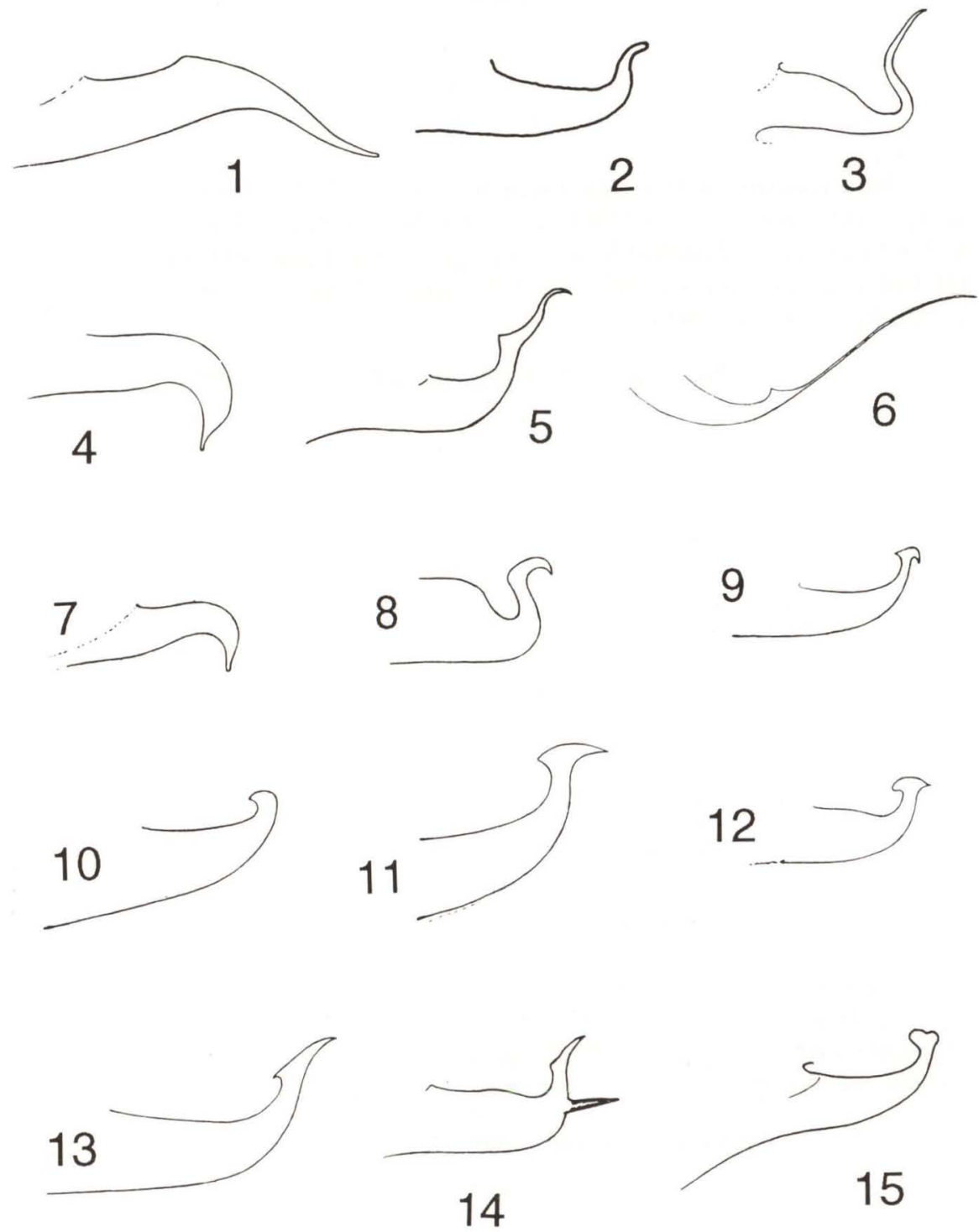

Figs 1-15. Aedeagi. (1) Eotetranychus lewisi (McGregor); (2) Schizotetranychus paezi Alvarado \& Freitez; (3) Oligonychus grypus Baker \& Pritchard; (4) O. punicae (Hirst); (5) O. gossypii (Zacher); (6) O. mcgregori Baker \& Pritchard; (7) O. ilicis (McGregor); (8) O. sacchari (McGregor); (9) Tetranychus desertorum Banks; (10) T. ludeni Zacher; (11) T. mexicanus (McGregor); (12) T. kanzawai Kishida; (13) T. marianae McGregor; (14) T. armipenis Flechtmann \& Baker; (15) T. neocaledonicus André. 


\section{Oligonychus gossypii (Zacher, 1920)}

Fig. 5

Paratetranychus gossypii Zacher, 1920. Ztschr. angew. Entomol. 7: 183.

Oligonychus gossypii, Pritchard \& Baker, 1955. Pacific Coast Entomol. Soc. Mem. Ser. 2: 359.

This species is known from Africa, Central America and Brazil on a variety of hosts.

New records: on Hevea brasiliensis Müll.Arg. (Euphorbiaceae), Rio Branco, Acre, (M. Fazolin leg., IX-1986) and Piracicaba, São Paulo, Brazil (CHWF leg., IV-1993); on a non identified Meliaceae, Agudos, São Paulo, Brazil (CHWF leg. XII-1982); on Sesbania grandiflora Poir (Fabaceae), Pivijay, Magdalena, Colombia (A. Madrigal leg., VI-1985).

\section{Oligonychus mcgregori (Baker \& Pritchard, 1953)}

Fig. 6

Paratetranychus mcgregori Baker \& Pritchard, 1953. Hilgardia 22 (7): 209.

Oligonychus mcgregori, Pritchard \& Baker, 1955. Pacific Coast Entomol. Soc. Mem. Ser. 2: 359.

This species was described from Nicaragua on cotton and is also known from Mexico, Costa Rica and Honduras on a few other plants.

New record: on Connarus sp. (Connaraceae), Agudos, São Paulo, Brazil (CHWF leg., XII-1982).

\section{Oligonychus ilicis (McGregor, 1917)}

Fig. 7

Tetranychus ilicis McGregor, 1917. Proc. U.S. Natl. Mus. 51 (2167): 586.

Paratetranychus ilicis, McGregor, 1919. Proc. U.S. Natl. Mus. 56 (2303): 673.

Oligonychus ilicis, Pritchard \& Baker, 1955. Pacific Coast Entomol. Soc. Mem. Ser. 2: 305.

This species is a pest of a variety of plants in the USA and Japan. In Brazil it is widely distributed on coffee. This mite lives almost exclusively on the top side of the host leaves causing bronzing and browning and premature leaf drop.

New records: on coffee, Coffea arabica L. (Rubiaceae), in Confiança, Roraima, Brazil (M. Melo leg., IX-1989); and on Eucalyptus spp. (Myrtaceae), Piracicaba, São Paulo, Brazil (CHWF leg., XII-1982), inside a greenhouse, next to infested coffee plants.

\section{Oligonychus sacchari (McGregor, 1942)}

Fig. 8

Paratetranychus sacchari McGregor, 1942. J. Univ. Puerto Rico 26: 91.

Oligonychus sacchari, Pritchard \& Baker, 1955. Pacific Coast Entomol. Soc. Mem. Ser. 2: 355.

Described from sugar cane in Puerto Rico, this species is also known from orchids and foxtail millet in the New Hebrides.

New record: on sugar cane, Saccharum officinarum L. (Poaceae), from Conceição da Barra, Espírito Santo, Brazil (A.F. Mendonça F. leg., XII-1990), where 120 hectares of sugar cane were heavily infested after a prolonged dry spell. 


\section{Tetranychus desertorum Banks, 1900}

Fig. 9

Tetranychus desertorum Banks, 1900. Tech. Bull. U.S. Dept. Agric. Div. Entomol. 8: 76.

The desert spider mite, as this species is known in the U.S. literature, has been reported from many plants in the USA, Mexico, Nicaragua, Peru, Brazil, Paraguay and Argentina, as well as in Japan.

New records: on Tectona grandis L. (Verbenaceae), Pivijay, Magdalena, Colombia (A. Madrigal leg., I-1985); on cotton, Gossypium hirsutum L. (Malvaceae), Espinal, Tolima, Colombia (A. Murillo leg., V-1984); on Vernonia sp. (Asteraceae), Ilha Sapeca, Parati, Rio de Janeiro, and Centratherium punctatum Cass. (Asteraceae), Parque Nacional do Itatiaia, Rio de Janeiro (CHWF leg., IV-1993 and XII-1993).

\section{Tetranychus ludeni Zacher, 1913}

Fig. 10

Tetranychus ludeni Zacher, 1913. Mitt. kaiserl. bio. -Anst. Land. -Forstw. 14: 40; Pritchard \& Baker, 1955. Pacific Coast Entomol. Soc. Mem. Ser. 2: 405.

This species is widespread throughout the tropics and reported from a wide range of plants.

New records: on apples, Malus communis Poir (Rosaceae), from Porto Alegre, Rio Grande do Sul, Brazil (F.Z. Cruz leg., I-1990); on Ricinus communis (L.) Müll. Arg. (Euphorbiaceae), from Itapeva, Minas Gerais, Brazil (CHWF leg., I-1993); on Cucumis melo L. (Cucurbitaceae), from Santo Tomé, Corrientes, Argentina (S. Caceres leg., VII-1994).

\section{Tetranychus mexicanus (McGregor, 1950)}

Fig. 11

Septanychus mexicanus McGregor, 1950. Amer. Midl. Nat. 44 (2): 323.

Tetranychus mexicanus, Pritchard \& Baker, 1955. Pacific Coast Entomol. Soc. Mem. Ser. 2: 411.

This species occurs on citrus and several other plants and is known from USA, Mexico, Brazil and Argentina.

New record: on Cedrela fissilis Vell. (Meliaceae), from Piracicaba, São Paulo, Brazil (CHWF leg., IX-1987) where it was observed on plants inside a greenhouse causing chlorotic leaf spotting and total defoliation.

\section{Tetranychus kanzawai Kishida, 1927}

Fig. 12

Tetranychus kanzawai Kishida, 1927. Zool. Mag. 39 (460): 105: Ehara, 1956: 504.

Tetranychus hydrangeae Pritchard \& Baker, 1955. Pacific Coast Entomol. Soc. Mem. Ser. 2: 425; Wainstein, 1960. Kazakh. Akad. Sel'sk. nauk. Nauch. Issled. Inst. Rast. Trudy 5: 1-276, new synonymy; Meyer, 1974. Dept. Agric. Techn. Serv. So. Afr. Entomol. Mem. (36): 227.

This species is known to occur in Asia and North America as a pest of tea 
and mulberry; it has also been taken from corn, hops, soybean, apple, grapes, citrus and other plants.

New record: on Hydrangea sp. (Saxifragaceae), from Parque Nacional, Bogota, Colombia (A. Murillo leg., V-1984).

\section{Tetranychus marianae McGregor, 1950}

Fig. 13

Tetranychus marianae McGregor, 1950. Amer. Midl. Natur. 44 (2): 291.

This is a pest of cotton and occurs also on castor bean, passionflower and orchids. It is known from Pacific islands, Florida, USA, Caribbean Islands, Nicaragua and Argentina.

New record: on Nicotiana tabacum L. (Solanaceae), from Camaquã, Rio Grande do Sul (C. Marcelo leg., III-1986) and Santa Cruz do Sul, Rio Grande do Sul, Brazil (N. Mahler leg., II-1980). A serious attack after a prolonged dry season was observed in both regions. Infested tobacco leaves turned yellow-whitish and after the maturing process had the aspect of charred paper without commercial value.

\section{Tetranychus armipenis Flechtmann \& Baker, 1970}

Fig. 14

Tetranychus armipenis Flechtmann \& Baker, 1970. Ann. Entomol. Soc. Amer. 63 (1): 162.

This species is known from Southern Brazil and Venezuela, on Sida sp.

New records: on Sida sp. (Malvaceae) Bella Vista, Corrientes, Argentina (S.Caceres leg., VI-1993) and on Sida rhombifolia L., Campinas, São Paulo, Brazil (I. Boselli leg., VII-1987).

\section{Tetranychus neocaledonicus André, 1933}

Fig. 15

Tetranychus neocaledonicus André, 1933. Bull. Mus. Hist. Nat. Paris, ser.2, 5: 302.

Referred to as the vegetable mite, this species has been reported on more than 100 plants including flowers, peach, coconut, and papaya from tropical and subtropical areas of the world, including Hawaii, Mauritius, Bahamas, Puerto Rico, USA, Mexico, Venezuela, Brazil and Argentina.

New records: on Bauhinia aculeata L. (Caesalpinaceae) and Codiaeum variegatum (L.) Blume (Euphorbiaceae) La Molina, Peru (U.G. Bacca leg., VI1983) and on Ricinus communis (L.) Müll. Arg. (Euphorbiaceae) Pacajus, Ceara, Brazil (F.V. Vieira leg., X-1987).

\section{Tetranychus urticae Koch, 1836}

Tetranychus urticae Koch, 1836. Deutsch. Crust. Myriap. Arachn. 1: 10.

The common two-spotted spider mite has also been known as the glasshouse

Revta bras. Zool. 13 (3): 569 - 578, 1996 
spider mite. These common names have referred to a complex that also included $T$. cinnabarinus (Boisduval), now a separate species. The published lists include the complex so it is not possible to segregate the hosts of each from the literature (JEPPSON et al. 1976).

Mites of this species complex have been recorded on more than 150 hosts which include most of the important agricultural crops and ornamental plants.

New records: on Impatiens balsamina L. (Balsaminaceae) La Molina, Lima, Peru (U.G. Bacca leg., IX-1983); on Rosa sp. (Rosaceae), Cochabamba, Bolivia (D. Mercado Z. leg., XII-1990); on chinese gooseberry, Actinida deliciosa (A. Chevalier) C.F. Liang \& A.R. Ferguson (Actinidaceae), Los Andes, Chile (R. Vargas M. leg., III-1988); on garlic, Allium sativum L. (Liliaceae), Itaporã, Mato Grosso do Sul, Brazil (P.E. Degrande leg., VIII-1985) on Eucalyptus spp. (Myrtaceae) Piracicaba, São Paulo, Brazil, (CHWF leg., XII-1982), inside a greenhouse: on corn, Zea mays L. (Poaceae) Montes Claros, Minas Gerais, Brazil (C.A.L. Oliveira leg., VII-1994), where a heavy infestation was observed on a corn field after a prolonged dry spell, although the crop was irrigated;

\section{Tetranychus cinnabarinus (Boisduval, 1867)}

Acarus cinnabarinus Boisduval, 1867. Entomol. Hort.: 88 .

Tetranychus cinnabarimus, Smith \& Baker, 1968. U.S. Dept. Agric. Coop. Econ. Inst. Rept. 18 (47): 1080; Boudreaux, 1956. Ann. Entomol. Soc. Amer. 49: 43.

The females of this mite are red. This species has been collected on many hosts thoughout the warmer parts of the world (see comments for previous species, T. urticae).

New records: on Broussonettia papyrifera Vent. (Moraceae), Brassaia actinophylla F. Muell. (Araliaceae), Bidens pilosa L. (Asteraceae), Abutilon reflexum L. (Malvaceae) and Malus silvestris L. (Rosaceae) La Molina, Lima, Peru (U.G. Bacca leg., IX-1983); on Dianthus caryophylla L. (Caryophyllaceae) Suba, Bogota, Colombia (A. Murillo leg., V-1984); on Vitis vinifera L. (Vitaceae) Casanova, Bahia, Brasil (S.J.Soria leg., X-1993).

\section{Tetranychus abacae Baker \& Pritchard, 1962}

Figs 16-25

Tetranychus abacae Baker \& Pritchard, 1962. Revta Soc. Mexic. Hist. Nat. 23: 329.

Tetranychus abacae was described from specimens collected from "Abaca sp.", from Costa Rica and Honduras, and from "banano", from Costa Rica, Honduras and Venezuela. I could not find a plant genus "Abaca" and, according to BAILEY \& BAILEY (1976), abaca, or manila hemp, is the common name of Musa textilis Née in the Phillipines. This ornamental plant has been widely distributed and is also known as abacá in Brazil and other Latinamerican countries and must be, therefore, the type host for T. abacae.

This species has not been further mentioned in literature and collects in Brazil indicate it is of wide distribution. 
Based on specimens collected in Brazil and on the original description, additional characters and figures are given. Measurements are in micrometers, average and range, $\mathrm{n}=10$ for females and males.

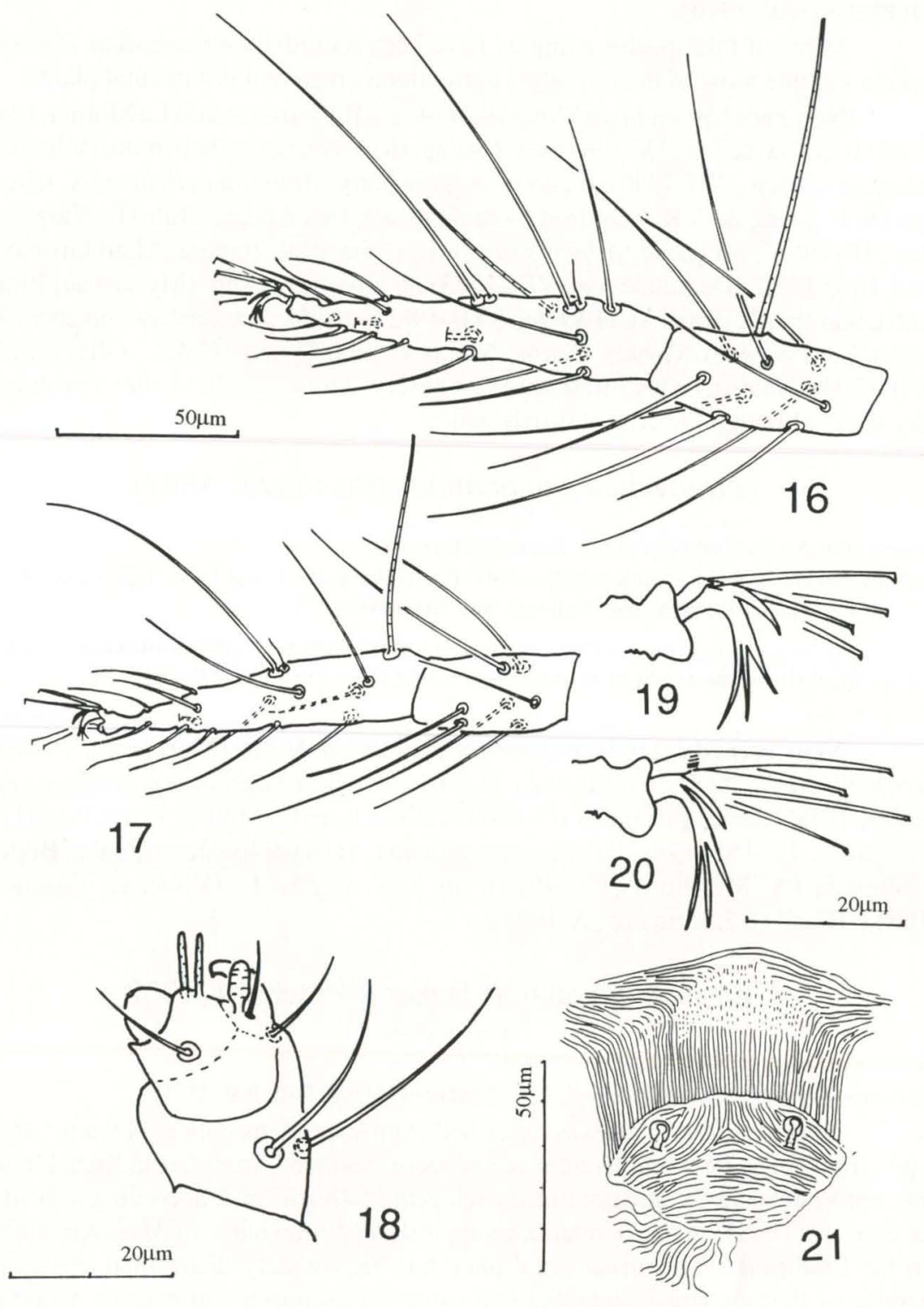

Figs 16-21. Tetranychus abacae Baker \& Pritchard, female. (16) Tarsus and tibia I; (17) tarsus and tibia II; (18) palptarsus and tibia; (19) ambulacrum I; (20) ambulacrum II; (21) pregenital area and genital flap. 


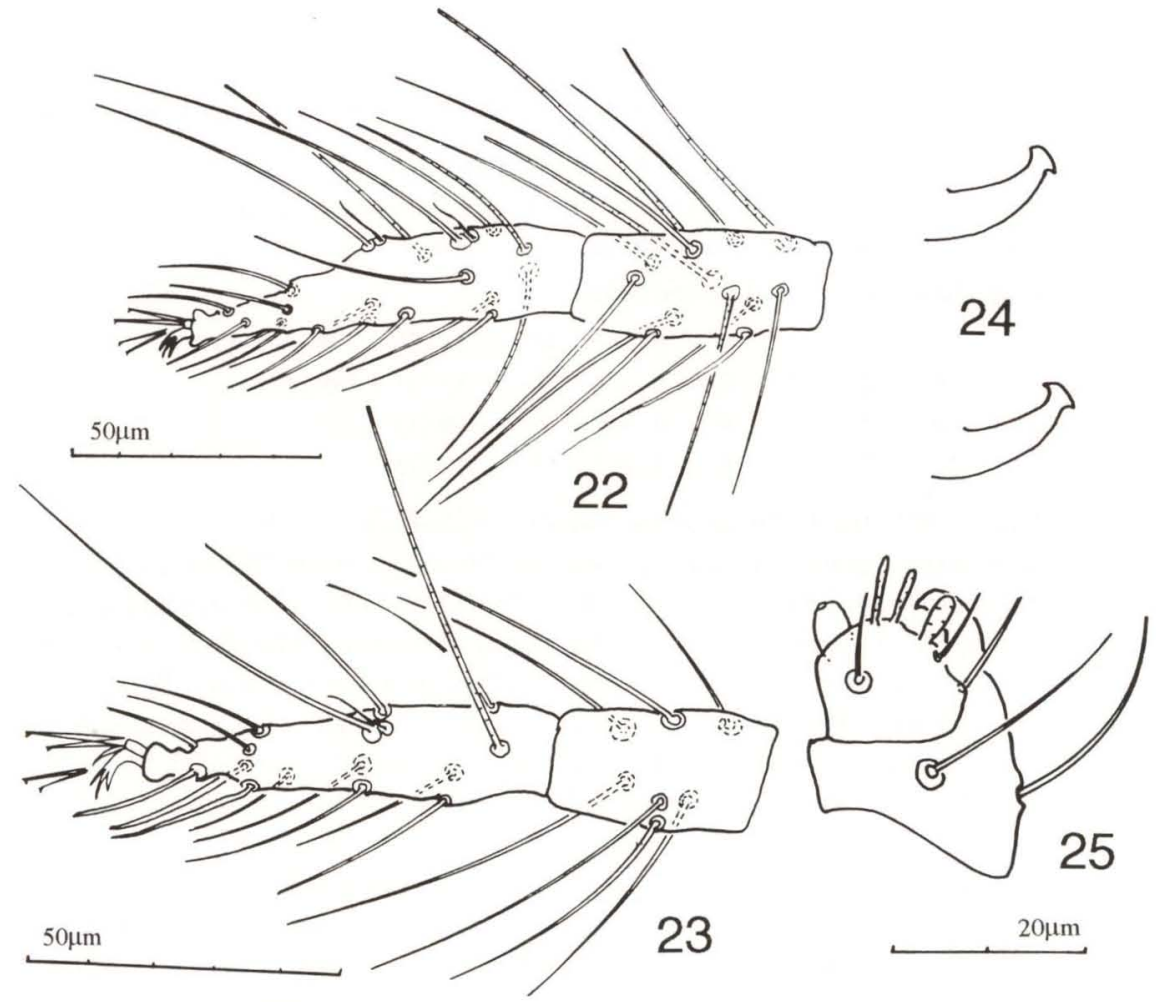

Figs 22-25. Tetranychus abacae Baker \& Pritchard, male. (22) Tarsus and tibia I; (23) tarsus and tibia II; (24) aedeagi; (25) palptarsus and tibia.

Female. Dorsal body setae long, extending beyond bases of the next two rows. Stylophore rounded anteriorly. Peritremes hooked distally. Prodorsal striae longitudinal; opisthosomal striae transverse but forming a diamond shaped pattern between setae $\mathrm{e}_{1}$ and $\mathrm{f}_{1}$ (urticae group). Pregenital area with longitudinal broken striae, flap with transverse, oblique and longitudinal striae. Spinneret (terminal sensillum of palp tarsus) short, robust, wider than long, with a small distal depression. Tarsus I with one tactile seta proximal to proximal duplex setae and three tactile setae in circumsegmental line with proximal duplex setae. Tibia I with nine tactile and one sensory (solenidium) setae. Empodia I-IV with dorsomedian spur, about half in length of the proximoventral hairs.

Leg chaetotaxy, from coxae to tarsi:

$$
\begin{array}{r}
\text { I- } 1-1-9-5-9(1)-13(1)+2 \text { duplexes } \\
\text { II }-2-1-6-5-7-13(1)+1 \text { duplex } \\
\text { III }-1-1-4-4-6-9(1) \\
\text { IV }-1-1-4-5-7-10(1)
\end{array}
$$

Body length, including gnathosoma 471 (420-513); width 271 (251-322), $\mathrm{n}=10$. 
Male. Similar to female. Empodium I unciform with a pronounced dorsomedian spur. Tarsus I with two sensory (solenidia) and three tactile setae proximal to proximal duplex setae and one sensory seta laterad to this duplex; tibia I with four tactile and nine sensory setae. Spinneret (terminal sensillum of palpus) about one and half times as long as wide. Aedeagus bend dorsad, head with subequal anterior and posterior angulations; dorsally rounded.

Leg chaetotaxy, from coxae to tarsi:

$$
\begin{aligned}
& \text { I }-2-1-9-5-9(4)-14(3)+2 \text { duplexes } \\
& \text { II }-2-1-6-5-7-13(1)+1 \text { duplex } \\
& \text { III }-1-1-4-4-6-9(1) \\
& \text { IV }-1-1-4-4-7-10(1)
\end{aligned}
$$

Body lenth, including gnathosoma $411(356-472) ; n=10$.

Specimens examined. 24 females and 16 males from Heliconia bihai L. (Heliconiaceae), Piracicaba, São Paulo, June, 1995 (CHWF); 6 females and 6 males from banana, Musa acuminata Colla (Musaceae), Piracicaba, São Paulo, June 1995 (CHWF); 15 females, 5 males, from banana, M. acuminata, Cotia and Porto Feliz, São Paulo (CHWF, 1967); 5 females and 2 males from banana, M. acuminata, Santa Catarina (?, 1970); 5 females and 4 males from banana, M. acuminata, Paranapanema, São Paulo (Fazenda Holambra, May, 1995). In the collection of Dept. Zoologia, Univ. S. Paulo-ESALQ, Piracicaba, São Paulo, Brazil.

Tetranychus abacae females are red in color. Large populations have been observed, both on Heliconia and bananas, during warm weather and after a prolonged dry period, usually at the end of the summer. They produce intense webbing, covering the entire lower surface of the leaves of their host plants; these leaves dry prematurely. With the onset of colder temperatures and/or rain, the populations are drastically reduced.

\section{REFERENCES}

BAKER, E.W. \& A.E. PRITCHARD. 1962. Arañas rojas de America Central. (Acarina:

Tetranychidae). Revta Soc. Mexic. Hist. Natur. 23: 309-340.

BAIley, L.H. \& E.Z. BAILEY. 1976. Hortus Third. McMillan, 1290p.

EHARA, S. 1956. Tetranychoid mites of mulberry in Japan. J. Fac. Sci. Hokkaido

Univ. (6) Zool. 12: 499-510.

JEPPSON, L.R.; H.H. KEIFER \& E.W. BAKER. 1976. Mites Injurious do Economic

Plants. Univ. California Press, 614p.

Recebido em 30.VIII. 1995; aceito em 25.X. 1996. 